\title{
Appraisal of Some Heavy Metals and Elements in Irrigated Vegetables and Fruit Cultivated in College Farm, Maiduguri, Nigeria
}

\author{
Gwana Adamu Mohammed, ", Bassey Effong Edet ${ }^{2}$, Hauwa Lawan Badawi ${ }^{3}$, \\ Halima Mohammed Bala ${ }^{4}$, Mustapha Umar Marte ${ }^{5}$, Ali Mohammed ${ }^{6}$, Laku Dauda ${ }^{7}$ \\ ${ }^{1}$ Laboratory Unit, A. H. P Department, Mohamet Lawan College of Agriculture, Maiduguri, Nigeria \\ ${ }^{2}$ Department of Microbiology and Brewery, Nnamdi Azikwe University, Awka, Nigeria \\ ${ }^{3}$ Heritage Unit, Department of Heritage and Museum Sites, National Commission for Museums and Monuments, Maiduguri, Nigeria \\ ${ }^{4}$ Department of Basic Science, Mohamet Lawan College of Agriculture, Maiduguri, Nigeria \\ ${ }^{5}$ Department of Animal Health and Production Technology, Mohamet Lawan College of Agriculture, Maiduguri, Nigeria \\ ${ }^{6}$ Department of Veterinary Microbiology and Parasitology, Faculty of Veterinary Medicine, University of Maiduguri, Maiduguri, Nigeria \\ ${ }^{7}$ Department of Veterinary Surgery and Theriogenology, Faculty of Veterinary Medicine, University of Maiduguri, Maiduguri, Nigeria
}

\section{Email address:}

admuwana@yahoo.com (Gwana A. M.), edetbassey69@gmail.com (Bassey E. E.), elbadawi@yahoo.com (Hauwa, L. B.), Halima.mohmmedbala@yahoo.com (Halima M. B.), umarmarte@yahoo.com (Mustapha U. M.), vetmadeali@gmail.com (Ali M.), ddlaku47@gmail.com (Laku D.)

\section{To cite this article:}

Gwana Adamu Mohammed, Bassey Effong Edet, Hauwa Lawan Badawi, Halima Mohammed Bala, Mustapha Umar Marte, Ali Mohammed, Laku Dauda. Appraisal of Some Heavy Metals and Elements in Irrigated Vegetables and Fruit Cultivated in College Farm, Maiduguri, Nigeria. International Journal of Applied Agricultural Sciences. Vol. 3, No. 3, 2017, pp. 78-86. doi: 10.11648/j.ijaas.20170303.14

Received: December 16, 2015; Accepted: February 8, 2016; Published: May 29, 2017

\begin{abstract}
This study was conducted to determine concentration levels of heavy metals and element in irrigated leafy vegetables and fruit cultivated at colleges' farm along river Kumodu Gana bank, Maiduguri. Samples were obtained randomly from five locations and analysed as described by AOAC, (1990). Cadmium, copper, iron, potassium, manganese, nickel, lead and zinc were determined in plant parts of spinach (Amaranthus blitum), jute wallow (Corchurus tridents), roselle (Habiscus sabdariffa variety), and fruits of pepper (Capsicum species). The results revealed mean concentration level of each element determined in the vegetable plants studied; for cadmium had $0.80-3.21 \mu \mathrm{g} / \mathrm{g}$, copper $(0.38-1.58 \mu \mathrm{g} / \mathrm{g})$, iron $(0.27-1.89$ $\mu \mathrm{g} / \mathrm{g})$, potassium $(6.6-27.13 \mu \mathrm{g} / \mathrm{g})$, manganese $(0.26-2.42 \mu \mathrm{g} / \mathrm{g})$, nickel $(0.23-4.21 \mu \mathrm{g} / \mathrm{g})$, lead $(0.32 \mu \mathrm{g} / \mathrm{g})$, and $0.13-0.74$ $\mu \mathrm{g} / \mathrm{g}$ for zinc. The magnitude of concentration levels of these elements detected in different irrigated vegetable plant parts materials' sequential order was $\mathrm{K}>\mathrm{Ni}>\mathrm{Cd}>\mathrm{Mn}>\mathrm{Fe}>\mathrm{Cu}>\mathrm{Zn}>\mathrm{Pb}$, the highest was potassium (K), the least was lead $(\mathrm{Pb})$ and $\mathrm{Pb}$ was detected in roselle (Habiscus sabdariffa variety) only. No significance differences between the plant parts when compared their concentration levels in term of the elements determined. Their concentrations are below the recommended safe limit proposed by AOAC, EU, FAO and WHO. Hence, irrigated vegetables cultivated in the studied area were found fit, wholesome for consumption and health risk free. Further studies on the same irrigated vegetables and area are recommended.
\end{abstract}

Keywords: Elements, Irrigated Vegetables, Metals, Mean Concentration, River Kumodu Gana, Safe Limit

\section{Introduction}

Urban and sub-urban foods production contributes to sense of communities [16]. It has social educationally and skill development benefits for societies, helping to nature cultural and horticultural knowledge of food production and usage. Urban and Peri - urban agriculture (UPA) is an alternative way of producing food within the cities. FOA defines UPA as "agricultural practices within and around cities which compete for resources (land, water, energy, and labour) that could also serve other purposes to satisfy the food requirement of the urban population". Food production can take place on rooftops and in backyard, community vegetable and fruit gardens and unused or public spaces $[30,8]$. 
Vegetables are extremely important life supporting plant parts materials for human beings and animals, this is because, vegetables contains essential component of nutrients and phytochemicals [16, 30, 8]. In addition to increasing the community's food security, urban agriculture can promote skill development, greening and community building, can potentially contribute to the household food supply and even create an important source of income, especially for the urban poor. Urban agriculture also creates employment opportunities within the community, and helps the local economy by keeping the money in the community [8, 34].

The consumption of vegetables and fruits as food offer rapid and least means of providing adequate vitamins supplies, minerals and fibres. Vegetables are used as food including those used in making soups or served as integral parts of the main sources of a meal [1]. Plants are conveniently separated into those which are edible, those which serves as a source of drugs or spices, those that are of ornamental value, and so forth. Although almost intensively cultured plant rightly comes under the domain of horticulture, primary effort is centred about the various traditional "garden" plants. The Horticulturist divides the edible garden plant into vegetables and fruits. Generally considered as vegetables are those herbaceous plants of which some portion is eaten, either cooked or raw, during the principal part of the meal. Common examples are spinach (edible leaf), asparagus (edible stem), beet (edible root), cauliflower (edible flower), eggplant (edible fruit) and pea (edible seed). Fruit, on the other hand, are plants from which a more or less succulent fruits or closely related structure is commonly eaten as a desert or snack. Fruits plants are most often perennial and are usually woody [13, 23]. Oxford Learner's Dictionary, defined vegetable as a plant or part of a plant that is eaten; e.g. potatoes, beans and onion are all vegetables. Green vegetable, e.g. lettuce, cabbage; Root vegetable, e.g. carrot; Leaf vegetable, e.g. spinach, sorrel, etc. Fruit was also defined as the part of a plant that consist of a stone, or pit or seeds and fresh, can be eaten as food and usually taste sweet, or a part of plant or tree that is formed after the flowers have died and in which seeds develop [18].

Consumption of food crops contaminated with heavy metals is a major food chain route for human exposure $[4,5$, 27]. The distribution of heavy metals in plant body depends upon availability and concentration of heavy metals as well as particular plant species and its population [29, 7, 2]. The heavy metals or trace elements play an important role in the metabolic pathways during the growth and development of plants, when available in required concentration [4, 28]. Many researchers have shown that some common vegetables are capable of accumulating high levels of metals from the soil [11, 19]. Certain species of these vegetables (e.g. cabbage) are hyper-accumulators of heavy metals into the edible tissues of plants [39].

Out of the one hundred and twelve (112) elements in nature, about eighty (80) are metals, most of which are found only in trace amounts in the biosphere and biological materials. Some metals or metal like elements which do give rise to well organised toxic effects in man and his ecological associates $[4,12,35,10]$. These elements include; arsenic, antimony, beryllium, cobalt, chromium, lead, manganese, nickel, e.t.c, $[15,25]$. These metals have been known to be toxic to man for centuries, and their carcinogenic activities have also been reviewed by Meittinien, (1975).

Among the different pollutants heavy metals have received escalating attention due to their possible injurious effects to man, animals and plants as there are recorded to be cytotoxic, mutagenic, and carcinogenic. Heavy metals are conventionally defined as elements with metallic properties such as ductility, conductivity, stability and cat-ions, legends specificity, etc, and atomic number greater than 20 . The most common heavy metals contaminants are arsenic, cadmium, chromium, copper, mercury, lead, nickel, vanadium and zinc. Heavy metals form the major group of toxic pollutants among the other pollutants, as these metals temper the harmony of the ecosystem [21,9]. Protection of environment is the most vital issue today; explosive population growth, rapid progress in science and technology, massive industrialisation and use of various chemicals in agriculture and most important, human activities are the factors threatening the very quality of life [32, 36, 37].

Despite of the bright prospects and enormous potential need of vegetables and fleshy fruits production in Nigeria, there are challenges such as Sanitised cultivation, Poor growth and harvesting techniques, lack of storage facilities, inadequate processing facilities, and improper packaging and pests' protection management procedures. These factors mentioned may lead to the contamination of the vegetables and fruits with the heavy metals and elements mentioned. Heavy metals are natural constituents in nature, usually occurring in low concentration under normal conditions. Anthropogenic activities can cause elevated levels of these metals in various parts of the ecosystem and thus environmental pollution by heavy metals may occur via various diffused and point sources.

The objectives of this study are to determine some heavy metals and elements in irrigated vegetables and fruits cultivated in the College farm, Mohamet Lawan College of Agriculture, along river Kumodu Gana, Maiduguri. The study would be found significant and useful by revealing some of the heavy metal (cadmium, copper, iron, potassium, manganese, nickel, lead and zinc) means concentration levels in some plant parts of irrigated vegetables of spinach (Amaranthus blitum), jute wallow (Corchurus tridents) and roselle (Habiscus sabdariffa variety), and fruits of red hot pepper (Capsicum species) that was cultivated in the study area and consumed by human and animals as source of nutrients.

\section{Materials and Methods}

\subsection{Site Location}

The site of the farm is located along River Kumodu Gana 
bank, which started down from Alau basin (Alau dam) to Gwange area where it met with River Ngada Bul which discharged its content, and where it goes down to colleges' farm site and terminated down at Jere basin, where then it discharged and disbursed its contents into the field (basin), down to Chad basin area (Gwana et. al, 2013). The River Kumodu Gana passes through the middle of Maiduguri Metropolis from the south to down north, dividing Maiduguri into two parts, thus, eastern and western Maiduguri, where by most of the domestic wastes produces by the habitats, waste waters from Abattoir, Tannery, e.t.c, are discharge and channel into the river, thereby polluting the waters.

\subsection{Materials}

Materials (Apparatus and reagents) used in this research study were of high grade, AOAC standard reagents and the determinations of minerals in the plant part materials was by using the Atomic Absorption Spectrophotometer of the 210 VGP -Buck model. SOP was strictly being observed.

\subsubsection{Reagent}

6 Molar hydrochloric acid $(\mathrm{HCl})$, concentrated nitric acid $\left(\mathrm{HNO}_{3}\right)$, distilled water, deionised water, and AOAC Standard Reagents.

\subsubsection{Apparatus}

Plastic spatula, filter paper, hot plate, furnace, volumetric flasks, beakers, crucible dish, hand gloves, analytical balance, atomic absorption spectrophotometer (AAS), pistle and motor, and Plastic sieve.

\subsection{Methods}

\subsubsection{Sampling and Samples Collection}

The site of the farm is located along River Kumodu Gana bank, at early hours (06: $30 \mathrm{am}$ ) in the morning, 4 fresh samples of the irrigated plant parts materials (3 leafy vegetables and fruit; spinach (Amaranthus blitum), Jute plant (Corchurus tridents) and Roselle (Habiscus sabdariffa variety) and red hot pepper (Capsicum species) were obtained directly from the garden farm randomly from five locations. These plant materials varieties were pooled and packed in polythene bag each, labelled and transported to the Laboratory. In laboratory, the samples were washed successively under tap water gently, acidified water, distilled water and doubled or repeated with distilled water gently. Moisture and water droplets were removed with the aid of blotting papers. These samples were then dried, first at room temperature for several days and then in hot air oven at $60 \pm$ $5^{\circ} \mathrm{C}$ for 48 hours, as described by Ashiq et al., (2013). Fresh and dried weights of the samples were determined, as described by Akan et al., (2013).

\subsubsection{Ashing the Samples}

Air dried plant parts materials (vegetables and fruits) were pulverized in to powder, transferred into crucible dish and put to muffle furnace, heated at $500^{\circ} \mathrm{C}$ for 3 hours. It was then removed and allowed in a desiccator to cooled and dried, as described by Ashiq et al., (2013).

\subsubsection{Digestion of the Samples}

$0.5 \mathrm{~g}$ of the ashed samples was transferred into $250 \mathrm{ml}$ beaker each. $10 \mathrm{ml}$ of $6 \mathrm{M}$ Hydrochloric acid were also added to each and covered the beaker with watch glass and heated for 15 minutes, removed and cooled. $1 \mathrm{ml}$ of concentrated Nitric acid was added and heated to evaporate to dryness and dehydrated the Sillica. $1 \mathrm{ml}$ of $6 \mathrm{M}$ of Hydrochloric acid was added again. $10 \mathrm{ml}$ of distilled water was added and heated to redissolved, cooled and filtered with Filter paper Whatman No 541 into $100 \mathrm{ml}$ volumetric flask up to the mark levelled. It was then transferred into polythene bottle for elements analysis, as described by AOAC, (1990).

\subsubsection{Method of Elements Analysis}

The method applied in the evaluations of some mineral composition of each sample of plant materials, after the Ashing and the digestion of the samples was by using the Atomic Absorption Spectrophptometric techniques as described by AOAC, (1990).

\subsection{Data Analysis}

Data obtained from this research study was subjected to statistical tools of analysis using mean for the measurement of central tendency, and standard deviations for measurement of dispersion and or discrepancy within the variables being obtained and its' significance, as described by Stroud and Booth, (2001)

\section{Results}

The results obtained from this study revealed that, some heavy metals and other elements were screened and evaluated in some plant parts materials (stems, leaves and fruit) of four different irrigated vegetables, which consist of fruit of hot red pepper (Capsicum species) and leafy vegetables; Spinach (Amaranthus blitum), Jute wallow (Corchurus tridents) and Roselle (Habiscus sabdariffa variety)) of which were cultivated in the College Irrigation farm site. The concentration levels of eight (8) elements (Cadmium, Copper, Iron, Potassium, Manganese, Nickel, Lead and Zinc) in microgram per gram $(\mu \mathrm{g} / \mathrm{g})$ were determined and evaluated, and the results are in conformity with the values reported by most researchers; Ibrahim and Jimoh, (2015); Jimoh and Mahmud, (2012); Awode et al, (2008); etc. The results are presented in mean concentration levels and standard deviations of each element in each plant part material concerned as presented in the tables as follows:

Table 1 shows the concentration levels of some heavy metals and elements determined in spinach leaves and stems. The stems revealed the mean concentration levels of the elements evaluated of $0.83 \pm 0 \mu \mathrm{g}, 1.58 \pm 0.01 \mu \mathrm{g}, 1.89 \pm 0 \mu \mathrm{g}$, $27.13 \pm 0.1 \mu \mathrm{g}, 0.61 \pm 0.01 \mu \mathrm{g}, 1.32 \pm 0.01 \mu \mathrm{g}$ and $0.13 \pm 0 \mu \mathrm{g}$ for $\mathrm{Cd}, \mathrm{Cu}, \mathrm{Fe}, \mathrm{K}, \mathrm{Mn}, \mathrm{Ni}$ and $\mathrm{Zn}$, but Lead $(\mathrm{Pb})$ not detected, while the leaves contained the mean concentration levels of the elements evaluated of $0.82 \pm 0.01 \mu \mathrm{g}, 1.57 \pm 0.01 \mu \mathrm{g}$, 
$1.88 \pm 0.01 \mu \mathrm{g}, \quad 27.03 \pm 0.1 \mu \mathrm{g}, \quad 0.61 \pm 0 \mu \mathrm{g}, \quad 1.32 \pm 0.01 \quad$ and $0.11 \pm 0.01 \mu \mathrm{g}$ for $\mathrm{Cd}, \mathrm{Cu}, \mathrm{Fe}, \mathrm{K}, \mathrm{Mn}, \mathrm{Ni}$ and $\mathrm{Zn}$, also $\mathrm{Pb}$ was not detected. That is, lead $(\mathrm{Pb})$ was not detected in both the stems and the leaves of spinach respectively.

Table 2, it showed the mean concentration levels of some heavy metals and elements detected in Jute wallow (Corchurus tridents) stems and leaves; the stems of the vegetable revealed the mean concentration levels of the elements of $\quad 0.96 \pm 0 \mu \mathrm{g}, \quad 0.38 \pm 0.01 \mu \mathrm{g}, \quad 0.27 \pm 0.01 \mu \mathrm{g}$, $6.61 \pm 0.01 \mu \mathrm{g}, 0.26 \pm 0.01 \mu \mathrm{g}, 4.21 \pm 0.01 \mu \mathrm{g}$, and $0.13 \pm 0.01 \mu \mathrm{g}$ for $\mathrm{Cd}, \mathrm{Cu}, \mathrm{Fe}, \mathrm{K}, \mathrm{Mn}, \mathrm{Ni}$ and $\mathrm{Zn}$. Lead $(\mathrm{Pb})$ was not detected. While the leaves of Jute wallow revealed the mean concentration levels of the elements determined of $0.95 \pm 0 \mu \mathrm{g}$, $0.38 \pm 0.01 \mu \mathrm{g}, \quad 0.25 \pm 0 \mu \mathrm{g}, \quad 6.60 \pm 1.1 \mu \mathrm{g}, \quad 0.24 \pm 0 \mu \mathrm{g}$, $4.10 \pm 0.01 \mu \mathrm{g}$, and $0.13 \pm 0.0$, also $\mathrm{Pb}$ was not detected. That is, lead $(\mathrm{Pb})$ was not detected in both the stems and the leaves of Jute wallow respectively.

Table 3 showed the mean concentration levels of some heavy metals and elements detected in stems and leaves of roselle (Habiscus sabdariffa) variety of plant; the stems of the vegetable revealed the mean concentration levels of the elements of $\quad 3.11 \pm 0.01 \mu \mathrm{g}, \quad 0.59 \pm 0.01 \mu \mathrm{g}, \quad 0.82 \pm 0 \mu \mathrm{g}$, $14.04 \pm 0.01 \mu \mathrm{g}, 2.42 \pm 0.01 \mu \mathrm{g}, 0.63 \pm 0.01 \mu \mathrm{g}, 0.32 \pm 0.01 \mu \mathrm{g}$ and $0.30 \pm 0.01 \mu \mathrm{g}$, while the leaves of the said vegetable contained of the elements of $3.10 \pm 0 \mu \mathrm{g}, \quad 0.57 \pm 0 \mu \mathrm{g}$, $0.81 \pm 0.01 \mu \mathrm{g}, 14.0 \pm 0 \mu \mathrm{g}, 2.40 \pm 0.01 \mu \mathrm{g}, 0.63 \pm 0 \mu \mathrm{g}, 0.30 \pm 0 \mu \mathrm{g}$ and $0.29 \pm 0.01 \mu \mathrm{g}$ for $\mathrm{Cd}, \mathrm{Cu}, \mathrm{Fe}, \mathrm{K}, \mathrm{Mn}, \mathrm{Ni}, \mathrm{Pb}$ and respectively.

Table 4 showed the mean concentration levels of some heavy metals and elements detected in stems and leaves of hot red pepper (commonly called "Attargu" in Hausa language) variety of plant; the fruit of the vegetable revealed the mean concentration levels of the elements of $3.21 \pm 0.01 \mu \mathrm{g}, \quad 0.70 \pm 0.01 \mu \mathrm{g}, \quad 0.67 \pm 0.01 \mu \mathrm{g}, \quad 16.20 \pm 0.1 \mu \mathrm{g}$, $0.56 \pm 0 \mu \mathrm{g}, 0.23 \pm 0.01 \mu \mathrm{g}$, and $0.74 \pm 0.01 \mu \mathrm{g}$ for $\mathrm{Cd}, \mathrm{Cu}, \mathrm{Fe}$, $\mathrm{Mn}, \mathrm{Ni}$, and $\mathrm{Zn}$, but lead $(\mathrm{Pb})$ was not detected. The leaves of the said vegetable plant material contained the elements of the values $3.10 \pm 0 \mu \mathrm{g}, 0.69 \pm 0.01 \mu \mathrm{g}, 0.65 \pm 0 \mu \mathrm{g}, 16.07 \pm 0.1 \mu \mathrm{g}$, $0.55 \pm 0.01 \mu \mathrm{g}, 0.23 \pm 0 \mu \mathrm{g}$, and $0.72 \pm 0 \mu \mathrm{g}$ for $\mathrm{Cd}, \mathrm{Cu}, \mathrm{Fe}, \mathrm{K}$, $\mathrm{Mn}, \mathrm{Ni}$ and $\mathrm{Zn}$, also lead $(\mathrm{Pb})$ was not detected in the leaves of this vegetable plant part material. Both the fruit and the leaves of the said plant part material, lead were not detected.

Table 1. Mean Concentration levels of some Heavy Metals and Elements Determined in Spinach (Amaranthus blitum) Plant Parts Materials.

\begin{tabular}{|c|c|c|c|c|c|c|c|c|}
\hline \multirow{2}{*}{ Samples' Part. } & \multicolumn{8}{|c|}{ Mean Concentration of Metal in microgram per gram. } \\
\hline & Cd & $\mathrm{Cu}$ & Fe & $\mathbf{K}$ & Mn & $\mathbf{N i}$ & $\mathbf{P b}$ & Zn \\
\hline Stems. & $0.83 \pm 0.01$ & $1.58 \pm 0.01$ & $1.89 \pm 0$ & $27.13 \pm 0.1$ & $0.61 \pm 0.01$ & $1.32 \pm 0.01$ & ND & $0.13 \pm 0$ \\
\hline Leaves. & $0.82 \pm 0.01$ & $1.57 \pm 0.01$ & $1.88 \pm 0.01$ & $27.03 \pm 0.1$ & $0.6 \pm 0$ & $1.32 \pm 0.01$ & ND & $0.11 \pm 0.01$ \\
\hline Safe limit $(\mathrm{mg} / \mathrm{kg}) *$ & 0.01 & 10 & 1.3 & - & 3 & - & 2.5 & 5 \\
\hline
\end{tabular}

*SOURCE: WHO / AOAC, safe limit, revision 2, section $973-42 \mathrm{~B}$ (b).

Table 2. Mean Concentration levels of some Heavy Metals and Elements Determined in Jute wallow (Corchurus tridens) Plant Parts Materials.

\begin{tabular}{llllllll}
\hline \multirow{2}{*}{ Samples' Part. } & \multicolumn{2}{l}{ Mean Concentration of Metal in microgram per gram. } & & \\
\cline { 2 - 7 } & $\mathbf{C d}$ & $\mathbf{C u}$ & $\mathbf{F e}$ & $\mathbf{K}$ & $\mathbf{M n}$ & $\mathbf{N i}$ \\
\hline Stems. & $0.96 \pm 0.01$ & $0.38 \pm 0.01$ & $0.27 \pm 0.01$ & $6.61 \pm 0.01$ & $0.26 \pm 0.01$ & $4.21 \pm 0.01$ & $\mathrm{ND}$ \\
Leaves. & $0.95 \pm 0.01$ & $0.38 \pm 0.01$ & $0.25 \pm 0$ & $6.60 \pm 1.1$ & $0.24 \pm 0$ & $4.1 \pm 0.01$ & $\mathrm{ND}$ \\
*Safe limit (mg/kg) & 0.01 & 10 & 1.3 & - & $3.0 \mathrm{~m}$ & - & $0.13 \pm 0.01$ \\
\hline
\end{tabular}

*SOURCE: WHO / AOAC, safe limit, revision 2, section $973-42 \mathrm{~B}$ (b).

Table 3. Mean Concentration levels of some Heavy Metals and Elements Determined in Roselle (Habiscus sabdariffa l. Variety) Plant Parts Materials.

\begin{tabular}{|c|c|c|c|c|c|c|c|c|}
\hline \multirow{2}{*}{ Samples' Part. } & \multicolumn{8}{|c|}{ Mean Concentration of Metal in microgram per gram. } \\
\hline & Cd & $\mathrm{Cu}$ & Fe & $\mathbf{K}$ & Mn & $\mathrm{Ni}$ & $\mathbf{P b}$ & $\mathbf{Z n}$ \\
\hline Stems. & $3.11 \pm 0.01$ & $0.59 \pm 0.01$ & $0.82 \pm 0$ & $14.04 \pm 0.01$ & $2.42 \pm 0.01$ & $0.63 \pm 0.01$ & $0.32 \pm 0.01$ & $0.30 \pm 0.01$ \\
\hline Leaves. & $3.10 \pm 0$ & $0.57 \pm 0$ & $0.81 \pm 0.01$ & $14.0 \pm 0$ & $2.40 \pm 0.01$ & $0.63 \pm 0$ & $0.30 \pm 0$ & $0.29 \pm 0.01$ \\
\hline *Safe limit (mg/kg) & 0.01 & 10 & 1.3 & - & 3 & - & 2.5 & 5 \\
\hline
\end{tabular}

*SOURCE: WHO / AOAC, safe limit, revision 2, section 973 - 42B (b).

Table 4. Mean Concentration levels of some Heavy Metals and Elements Determined in Red hot Pepper (Capsicum species) Plant Parts Materials.

\begin{tabular}{|c|c|c|c|c|c|c|c|c|}
\hline \multirow{2}{*}{ Samples' Part. } & \multicolumn{8}{|c|}{ Mean Concentration of Metal in microgram per gram. } \\
\hline & Cd & $\mathrm{Cu}$ & $\mathrm{Fe}$ & $\mathbf{K}$ & Mn & $\mathbf{N i}$ & $\mathbf{P b}$ & $\mathbf{Z n}$ \\
\hline Stems. & $3.21 \pm 0.01$ & $0.70 \pm 0.01$ & $0.67 \pm 0.01$ & $16.2 \pm 0.1$ & $0.56 \pm 0$ & $0.23 \pm 0.01$ & ND & $0.74 \pm 0.01$ \\
\hline Fruits & $3.10 \pm 0$ & $0.69 \pm 0.01$ & $0.65 \pm 0$ & $16.07 \pm 0.1$ & $0.55 \pm 0.01$ & $0.23 \pm 0$ & ND & $0.72 \pm 0.01$ \\
\hline *Safe limit $(\mathrm{mg} / \mathrm{kg})$ & 0.01 & 10 & 1.3 & - & 3 & - & 2.5 & 5 \\
\hline
\end{tabular}

*SOURCE: WHO / AOAC, safe limit, revision 2, section 973 - 42B (b).

\section{Discussion}

Vegetables are used as food, and being a source of foods, either cooked or raw are eaten, these could be vegetable plant parts such as roots, stems, leaves, fruits, seeds or both. Vegetables such as lettuce, roselle, etc are leafy vegetable. Carrot, etc are root vegetables; spinach, etc are stem and leafy vegetable, while vegetables such as okra, pepper, 
orange, etc are fruits. Vegetables are source of minerals (essential elements), vitamins, proteins, oil, carbohydrates, phytochemicals which serves as nutrition and source of medicinal materials, e.g. antioxidants. Due to the human activities, the global warming and contamination by industrial wastes materials to the environments may lead to excessive release of some metals to waters and soils, e.g. rivers and streams. Therefore, this may lead to bioaccumulation in edible plants, thereby causing or may cause unsafe and insecurity for foods. The distribution of heavy metals and essential elements in plant body depends upon availability, $\mathrm{P}^{\mathrm{H}}$ and concentration of heavy metals as well as particular plant species and its population, which was proved in this study that, among the irrigated vegetables plant parts materials determined, only roselle that lead $(\mathrm{Pb})$ was detected, this was also reported by Ibrahim and Jimoh, (2015), Qais et al, (2013); Muhammad et al, (2008); Okoronkwo et al, (2005); Bhata, (2002) among others. The consumption of food crops contaminated with heavy metals is the food chain route for human and animal's exposure and is the major bioaccumulation of these metals, which may exceed the standard safe limit, i.e. standard recommended values by AOAC, EU, (2006); FAO/ WHO, (2007).

The determinations of some heavy metals and elements in irrigated vegetables and fruit plant parts materials were restricted to those that are cultivated in the College's irrigation farm. The site of the farm is located along River Kumodu Gana bank, which started down from Alau basin (Alau dam) to Gwange area where it met with River Ngada Bul which discharged its content, and where it goes down to colleges' farm site and terminated down at Jere basin, where then it discharged and disbursed its contents into the field (basin), down to Chad basin area (Gwana et. al, 2013). The River Kumodu Gana passes through the middle of Maiduguri Metropolis from the south to down north, dividing Maiduguri into two parts, thus, eastern and western Maiduguri, where by most of the domestic wastes produces by the habitats, waste waters from Abattoir, Tannery, e.t.c, are discharge and channel into the river, thereby polluting the waters.

The results of the analysis revealed that some heavy metals and elements screened and determined in spinach (Amanranthus blitum; called in Hausa language as Aleyafu, while in Kanuri language is known as alaifo) plant parts were that, the stems contained more concentration levels of potassium $(27.13 \mu \mathrm{g} / \mathrm{g})$, then followed by iron $(1.89 \mu \mathrm{g} / \mathrm{g})$, copper $(1.58 \mu \mathrm{g} / \mathrm{g})$, nickel $(1.32 \mu \mathrm{g} / \mathrm{g})$, cadmium $(0.83 \mu \mathrm{g} / \mathrm{g})$, manganese $(0.61 \mu \mathrm{g} / \mathrm{g})$ and least in concentration is zinc $(0.13 \mu \mathrm{g} / \mathrm{g})$; in the sequential order of $\mathrm{K}>\mathrm{Fe}>\mathrm{Cu}>\mathrm{Ni}>$ $\mathrm{Cd}>\mathrm{Mg}>\mathrm{Zn}$. While the leaves contained some elements in concentration levels of more potassium $(27.03 \mu \mathrm{g} / \mathrm{g})$, iron $(1.88 \mu \mathrm{g} / \mathrm{g})$, copper $(1.57 \mu \mathrm{g} / \mathrm{g})$, nickel $(1.32 \mu \mathrm{g} / \mathrm{g})$, cadmium $(0.82 \mu \mathrm{g} / \mathrm{g})$, manganese $(0.61 \mu \mathrm{g} / \mathrm{g})$, and least in concentration levels was found to be zinc $(0.11 \mu \mathrm{g} / \mathrm{g})$; $(\mathrm{K}>$ $\mathrm{Fe}>\mathrm{Cu}>\mathrm{Ni}>\mathrm{Cd}>\mathrm{Mg}>\mathrm{Zn})$. The results revealed that there was no lead, that is, lead was not detected in both stems and leaves of the plants material (spinach), which is in line with the work of Ibrahim and Jimoh, (2015). Among all the elements that were detected in the spinach plant parts material, only potassium that had slight difference in concentration level when compared between the stems and the leaves of the plant, but the rest had no significant differences and the concentration levels detected does not exceed the standard recommended levels or safe limits.

In another finding, it revealed that the concentration levels of the elements determined in Jute wallow (Corchurus tridens; called in Hausa language as Karkashi, while in Kanuri language is known as kaulu bul) plant parts were found in moderate levels. The stems had the greatest concentration level of potassium $(6.61 \mu \mathrm{g} / \mathrm{g})$, then followed by nickel $(4.21 \mu \mathrm{g} / \mathrm{g})$, cadmium $(0.96 \mu \mathrm{g} / \mathrm{g})$, copper $(0.38$ $\mu \mathrm{g} / \mathrm{g})$, iron $(0.27 \mu \mathrm{g} / \mathrm{g})$, manganese $(0.26 \mu \mathrm{g} / \mathrm{g})$ and the least was zinc $(0.13 \mu \mathrm{g} / \mathrm{g})$; in the sequence of the descending order of concentration levels of $\mathrm{K}>\mathrm{Ni}>\mathrm{Cd}>\mathrm{Cu}>\mathrm{Fe}>\mathrm{Mn}>\mathrm{Zn}$ respectively. It revealed that the leaves were found to contained the concentration levels of the elements determined that potassium had the highest concentration level $6.60 \mu \mathrm{g} / \mathrm{g}$, followed by nickel with the concentration level of $4.10 \mu \mathrm{g} / \mathrm{g}$, cadmium $(0.95 \mu \mathrm{g} / \mathrm{g})$, copper $(0.38 \mu \mathrm{g} / \mathrm{g})$, iron $(0.25 \mu \mathrm{g} / \mathrm{g})$, manganese $(0.24 \mu \mathrm{g} / \mathrm{g})$ and had the least concentration level of zinc with $0.13 \mu \mathrm{g} / \mathrm{g} ;(\mathrm{K}>\mathrm{N}$ i $>\mathrm{Cd}>$ $\mathrm{Cu}>\mathrm{Fe}>\mathrm{Mn}>\mathrm{Zn}$ in sequent). There are no significant differences in concentration levels of potassium, cadmium, copper, and zinc compared between the stems and the leaves of the plant Jut wallow. And all the elements screened and determined in the edible plant (Jute wallow) falls within the recommended values (safe limit), which is in conformity with the values obtained by Awode et al, (2008); Ibrahim and Jimoh, (2015). Lead was not detected in both stem and leaves; therefore, the stems and the leaves of this cultivated leafy vegetable in the said area contain no Lead.

The results obtained also revealed that, the mean concentration levels of the elements determined in the stems of Roselle (Habiscus sabdariffa) called in Hausa language as Yakuwa and in Kanuri language as Karasu, plant parts, were that, the potassium had the highest concentration level of $14.04 \mu \mathrm{g} / \mathrm{g}$, then followed by cadmium with $3.11 \mu \mathrm{g} / \mathrm{g}$, manganese $(2.42 \mu \mathrm{g} / \mathrm{g})$, iron $(0.82 \mu \mathrm{g} / \mathrm{g})$, nickel $(0.63 \mu \mathrm{g} / \mathrm{g})$, copper $(0.59 \mu \mathrm{g} / \mathrm{g})$, lead $(0.32 \mu \mathrm{g} / \mathrm{g})$ and finally zinc had least concentration level of $0.30 \mu \mathrm{g} / \mathrm{g}$; sequentially, in descending order of concentration levels $(\mathrm{K}>\mathrm{Cd}>\mathrm{Mn}>\mathrm{Fe}>\mathrm{Ni}>\mathrm{Cu}>$ $\mathrm{Pb} \mathrm{Zn).} \mathrm{The} \mathrm{leaves} \mathrm{had} \mathrm{the} \mathrm{mean} \mathrm{concentration} \mathrm{levels} \mathrm{of} \mathrm{the}$ same elements determined; that potassium had highest concentration level of $14.0 \mu \mathrm{g} / \mathrm{g}$, and $3.10 \mu \mathrm{g} / \mathrm{g}, 2.40 \mu \mathrm{g} / \mathrm{g}$, $0.82 \mu \mathrm{g} / \mathrm{g}, 0.63 \mu \mathrm{g} / \mathrm{g}, 0.57 \mu \mathrm{g} / \mathrm{g}, 0.30 \mu \mathrm{g} / \mathrm{g}$ and $0.29 \mu \mathrm{g} / \mathrm{g}$ for cadmium, manganese, iron, nickel, copper, lead and zinc had the least concentration level $(\mathrm{K}>\mathrm{Cd}>\mathrm{Mn}>\mathrm{Fe}>\mathrm{Ni}>\mathrm{Cu}>$ $\mathrm{Pb}>\mathrm{Zn}$ ) respectively. Thus, both the stems and the leaves had almost no significance in values when compared between their concentration levels and they contained lead in very small amount. The stems and leaves are found wholesome and safe for consumption, this is because, the values that were obtained from these plant parts materials did not exceeded the standard recommended values or safe limit.

The study also revealed that, some heavy metals and 
elements in vegetable fruit of red hot pepper plant (Capsicum specie) 'Attargu' in Hausa language and in Kanuri language known as 'Njitta kuji', that was cultivated in the College farm and determined; the highest in concentration levels in stems was found to be potassium with the concentration level of $16.20 \mu \mathrm{g} / \mathrm{g}$, while the rests had $3.21 \mu \mathrm{g} / \mathrm{g}$ for cadmium, $0.74 \mu \mathrm{g} / \mathrm{g}$ for zinc, $0.70 \mu \mathrm{g} / \mathrm{g}$ for copper, $0.67 \mu \mathrm{g} / \mathrm{g}$ for iron, $0.56 \mu \mathrm{g} / \mathrm{g}$ for manganese, and $0.23 \mu \mathrm{g} / \mathrm{g}$ for Nickel which is the lowest in concentration level. Thus, the sequence of concentration levels in descending order is as follow; $\mathrm{K}>$ $\mathrm{Cd}>\mathrm{Zn}>\mathrm{Cu}>\mathrm{Fe}>\mathrm{Mn}>\mathrm{Ni}$. Lead was not detected in the stems of this plant parts material. With regards to the leaves of the same plant material, it contained these elements in concentration levels of; $16.07 \mu \mathrm{g} / \mathrm{g}$ for potassium which is the highest, and the lowest is nickel with a concentration level of $0.23 \mu \mathrm{g} / \mathrm{g}$. The rest had the following concentration levels of cadmium $(3.10 \mu \mathrm{g} / \mathrm{g})$, zinc $(0.72 \mu \mathrm{g} / \mathrm{g})$, copper $(0.69$ $\mu \mathrm{g} / \mathrm{g})$, iron $(0.65 \mu \mathrm{g} / \mathrm{g})$ and manganese with $0.55 \mu \mathrm{g} / \mathrm{g}$. The concentration levels sequence in descending order is as followed; $\mathrm{K}<\mathrm{Cd}>\mathrm{Zn}>\mathrm{Cu}>\mathrm{Fe}>\mathrm{Mn}>\mathrm{Ni}$. Lead was not detected also in the leaves of the plant part material (Red hot pepper), hence, lead was not present in both the stems and the leaves, and that is, they are lead free vegetable plant parts in the said cultivated area. There are no significance differences between the stems and leaves of this plant parts material when compared their concentration levels in term of copper, iron, nickel and zinc their concentration levels falls within the recommended safe limit, which is inconformity with the values obtained by Awode et al, (2008); Jimoh and Mahmud, (2012). Hence, was found wholesome for consumption and health risk free.

The findings of the studied plant parts materials, i.e. the results also showed that, the mean range concentration levels of the elements (cadmium, copper, iron, potassium, manganese, nickel, lead and zinc) determined and evaluated in all the leafy and fruit vegetables plant part materials (spinach, jute wallow, roselle and red hot pepper), when compared each element determined in all of the four vegetable plants being analysed were that for cadmium is $3.21 \mu \mathrm{g} / \mathrm{g}$ to $0.8 \mu \mathrm{g} / \mathrm{g}$, copper $(1.58 \mu \mathrm{g} / \mathrm{g}$ to $0.38 \mu \mathrm{g} / \mathrm{g})$, iron $(1.89 \mu \mathrm{g} / \mathrm{g}$ to $0.27 \mu \mathrm{g} / \mathrm{g})$, potassium $(27.13 \mu \mathrm{g} / \mathrm{g}$ to 6.61 $\mu \mathrm{g} / \mathrm{g})$, manganese $(2.42 \mu \mathrm{g} / \mathrm{g}$ to $0.26 \mu \mathrm{g} / \mathrm{g})$, nickel $(4.21 \mu \mathrm{g} / \mathrm{g}$ to $0.23 \mu \mathrm{g} / \mathrm{g})$, lead $(0.32 \mu \mathrm{g} / \mathrm{g})$ and $0.74 \mu \mathrm{g} / \mathrm{g}$ to $0.13 \mu \mathrm{g} / \mathrm{g}$ for zinc. The concentration levels magnitude of these elements detected in different kinds of the vegetable plant parts materials' was $\mathrm{K}>\mathrm{Ni}>\mathrm{Cd}>\mathrm{Mn}>\mathrm{Fe}>\mathrm{Cu}>\mathrm{Zn}>\mathrm{Pb}$, that is, the highest in concentration level was potassium $(\mathrm{K})$ and the least was lead $(\mathrm{Pb})$.

When considering the concentration levels of $\mathrm{Cd}$ in all of the vegetables plant parts in questioned, the leaves and fruits of hot pepper (Capsicum specie) had the highest with 3.10 $3.21 \mu \mathrm{g} / \mathrm{g}$, then followed by the leaves and stems of roselle with $3.10-3.11 \mu \mathrm{g} / \mathrm{g}$, the leaves and stems of jute wallow with $0.95-0.96 \mu \mathrm{g} / \mathrm{g}$ and most least in concentration of $\mathrm{Cd}$ among plant parts was the leaves and stems of spinach with $0.82-0.83 \mu \mathrm{g} / \mathrm{g}$. And the sequential order are as follow in terms of concentration of Cadmium in the said vegetables plant parts materials; Red hot pepper $>$ roselle $>$ jute wallow $>$ spinach. The concentration level of $\mathrm{Cd}$ in these irrigated vegetables plant parts was below the recommended value of $0.01 \mathrm{mg} / \mathrm{kg}$, and these are found wholesome and safe for consumption, this was in line with the works of Ibrahim and Jimoh, (2015), Jimoh and Mahmud (2012), and same with Ladipo and Doherty (2011) and Muhammad et. al., (2008), who appraised heavy metals in different vegetables and reported values below the recommended limit by WHO / FOA / AOAC.

With consideration to the concentration levels of $\mathrm{Cu}$ in all the vegetables plant parts materials being analysed, the highest in concentration level was the leaves and the stems of spinach with $1.57-1.58 \mu \mathrm{g} / \mathrm{g}$, followed by leaves and fruits of pepper had $0.69-0.70 \mu \mathrm{g} / \mathrm{g}$, then the leaves and the stems of roselle with $0.57-0.59 \mu \mathrm{g} / \mathrm{g}$ and the most least in concentration was jute wallow with $0.38 \mu \mathrm{g} / \mathrm{g}$ of the both plant parts mentioned. The vegetables sequential order in terms of $\mathrm{Cu}$ concentration levels are as spinach $>$ red hot pepper $>$ roselle $>$ jute wallow. The concentration of $\mathrm{Cu}$ in these irrigated vegetables plant parts was found be below the recommended value of $10.0 \mathrm{mg} / \mathrm{kg}$, and these are found wholesome and safe for consumption without any alarm for health risk, this was in line with the works of Ibrahim and Jimoh, (2015), Jimoh and Mahmud (2012), and same with Ladipo and Doherty (2011), who studied heavy metals in different vegetables and reported values below the recommended safe limit by AOAC / FAO / WHO.

With regard to the concentration levels of iron $(\mathrm{Fe})$ in all the four vegetables plant parts materials being determined, the most highest in concentration level was the leaves and the stems of spinach with $1.88-1.89 \mu \mathrm{g} / \mathrm{g}$, then leaves and the stems of roselle had $0.81-0.82 \mu \mathrm{g} / \mathrm{g}$, followed by the leaves and the fruits of red hot pepper $0.65-0.67 \mu \mathrm{g} / \mathrm{g}$, and the most least was the leaves and the stems of jute wallow had the concentration of iron content of $0.25-0.27 \mu \mathrm{g} / \mathrm{g}$ respectively. The irrigated vegetables plant parts materials sequential order in $\mathrm{Fe}$ concentration levels are as spinach $>$ roselle $>$ hot pepper $>$ jute wallow. The concentration of $\mathrm{Fe}$ in these irrigated vegetables plant parts was found to be below the recommended value $(1.30 \mathrm{mg} / \mathrm{kg})$, and these are found wholesome and safe for consumption without any expected health risk of this heavy metal in the said irrigated vegetable plant part and the studied area. This is in lined with the works of Ibrahim and Jimoh, (2015), Jayadev (2013), Kolawale (2011), Jimoh and Mahmud (2012), and same with Ladipo and Doherty (2011), who studied heavy metals in different vegetables and reported values below the recommended safe limit proposed by $\mathrm{AOAC} / \mathrm{EU} / \mathrm{FAO} /$ WHO.

In the same study, the concentration levels of the macro element potassium $(\mathrm{K})$ in all the vegetables plant parts determined, the most highest in concentration level was the leaves and the stems of spinach had $27.03-27.13 \mu \mathrm{g} / \mathrm{g}$, then the highest was the leaves and fruits of hot pepper with 16.07 $-16.20 \mu \mathrm{g} / \mathrm{g}$, the followed by the leaves and stems of roselle with $14.0-14.04 \mu \mathrm{g} / \mathrm{g}$ and finally the leaves and the stems of 
jute wallow which is least in concentration had $6.60-6.61$ $\mu \mathrm{g} / \mathrm{g}$ in level, and the sequential order of concentration level was spinach $>$ red hot pepper $>$ roselle $>$ jute wallow respectively. The irrigated vegetable plant parts materials are found to be wholesome and safe for consumption, this was in line with the works of Ibrahim and Jimoh, (2015), Jimoh and Mahmud (2012), and same with Ladipo and Doherty (2011), who appraised heavy metals in different vegetables and reported values below the recommended limit proposed by AOAC / EU / FAO / WHO.

The concentration levels of manganese (Mn) was also looked at, in all the vegetables plant parts determined, the most highest in concentration level was the leaves and the stems of roselle had $2.40-2.42 \mu \mathrm{g} / \mathrm{g}$, then the highest was the leaves and fruits of spinach both with $0.61 \mu \mathrm{g} / \mathrm{g}$, the followed by the leaves and fruits of pepper with $0.55-0.56$ $\mu \mathrm{g} / \mathrm{g}$ and finally the leaves and the stems of jute wallow which was least in concentration had $0.24-0.26 \mu \mathrm{g} / \mathrm{g}$. The sequential order of concentration level was roselle $>$ spinach $>$ pepper $>$ jute wallow respectively. The irrigated vegetable plant parts materials were found to be wholesome and safe for consumption, this was in line with the works of Akan et al., (2013), and same with Ladipo and Doherty (2011), determined heavy metals in different vegetables and reported values below the recommended safe limit $(3.0 \mathrm{mg} / \mathrm{kg})$ proposed by EU, FAO and WHO.

Also the concentration levels of nickel (Ni) in the four vegetables plant parts materials determined, the most highest in concentration level was the leaves and the stems of jute wallow had $4.10-4.21 \mu \mathrm{g} / \mathrm{g}$, then the leaves and stems of spinach both had concentration of the heavy metal (Ni) with $1.32 \mu \mathrm{g} / \mathrm{g}$, then followed by the leaves and stems of roselle with $0.63 \mu \mathrm{g} / \mathrm{g}$ and finally the leaves and the fruits of pepper which are least in concentration both had $0.23 \mu \mathrm{g} / \mathrm{g}$ in level, and the sequential order of concentration level was jute wallow $>$ spinach $>$ roselle $>$ pepper respectively. The concentration of $\mathrm{Ni}$ in irrigated vegetable plant parts materials are found to be below the safe limit, thus, are wholesome and safe for consumption without any expected health risk. It was in lined with the works of Ibrahim and Jimoh, (2015), Jimoh and Mahmud (2012), and same with Ladipo and Doherty (2011), who appraised heavy metals in different vegetables and reported values below the recommended limit proposed by EU / FAO / WHO.

The concentration of lead $(\mathrm{Pb})$ in all the plant parts materials analysed in present study were not detected except in the leaves and stems of roselle plant which had $0.30-0.32$ $\mu \mathrm{g} / \mathrm{g}$. And it is below the standard safe limit of $5.0 \mathrm{mg} / \mathrm{g}$ which was recommended by EU, FOA and WHO. Thus, the concentration levels in the studied irrigated vegetable plant part material was found wholesome for consumption by both human and animals, since there is no expected health risk of this heavy metal.

Lastly, the concentration level of the heavy metal zinc $(\mathrm{Zn})$ in each of the four vegetable plant parts materials were considered in this studied; the highest zinc concentration level among the irrigated vegetable plant parts materials was the leaves and fruits of red hot pepper had $0.72-0.74 \mu \mathrm{g} / \mathrm{g}$, then followed by the leaves and the stems of roselle had the concentration of $0.29-0.30 \mu \mathrm{g} / \mathrm{g}$, then both the leaves and the stems of jute wallow had $0.13 \mu \mathrm{g} / \mathrm{g}$, and finally the least was the leaves and stems of spinach had $0.11-0.13 \mu \mathrm{g} / \mathrm{g}$ respectively. The patterns of the sequential order of concentration of the irrigated plants was red hot pepper $>$ roselle $>$ jute wallow $>$ spinach. The values obtained from the analysed irrigated vegetable plants materials falls within the recommended safe limit, and were in line with the works of Ibrahim and Jimoh, (2015), Akan et al., (2013), Jimoh and Mahmud (2012), and same with Ladipo and Doherty (2011), who appraised heavy metals and essential elements in different irrigated vegetables and reported values below the recommended safe limit proposed by WHO / FAO / EU (2007).

These results were in support and conformity with the works of most Scientists and Researchers; Akan et. al., (2013); Ashiq et. al., (2013); Awofolu et. al., (2005); Qais et. al, (2013); Ibrahim and Jimoh, (2015), amongst others. From this study, the results obtained were found and concluded that the concentration levels of these elements determined in the said irrigated plant parts materials were below the safe limit proposed by WHO / AOAC / FAO for human consumption, it both met the national and International recommended values, hence, were found wholesome for consumption by both human beings and animals, thus there is no expected health risk of these elements within the studied water irrigated fed vegetables plant parts materials in the studied area.

\section{Conclusion}

Foods production contributes to sense of community and has social educational and skill development benefits for society, helping to nature cultural and horticultural knowledge of food production and usage. Vegetables are used as food, either cooked or raw are eaten, these could be vegetable plant parts such as roots, stems, leaves, fruits or both. Vegetables are source of minerals (essential elements), vitamins, proteins, oil, carbohydrates, phytochemicals which serves as nutrition and source of medicinal materials, e.g. antioxidants. Due to the human activities, farming, contamination of the environments with wastes materials may lead to excessive release of some metals to waters and soils, e.g. rivers and streams. The distribution of heavy metals and essential elements in plant body depends upon availability and concentration of heavy metals as well as particular plant species and its population. The consumption of food crops contaminated with heavy metals is the food chain route for human and animal's exposure and is the major bioaccumulation of these metals, which may exceed the standard safe limit, i.e. standard recommended values by WHO / AOAC / FAO. Some heavy metals and elements in irrigated vegetables and fruit plant parts materials that are cultivated in the College's irrigation farm, along River Kumodu Gana bank were being determined. The findings of 
the studied plant parts materials, i.e. the results revealed that, the mean range concentration levels of the elements (cadmium, copper, iron, potassium, manganese, nickel, lead and zinc) determined and evaluated in all the irrigated vegetables plant part materials (spinach, jute wallow, roselle and red hot pepper). Each element determined in all of the four vegetable plants being analysed were that for cadmium is $0.8-3.21 \mu \mathrm{g} / \mathrm{g}$, copper $(0.38 \mu \mathrm{g} / \mathrm{g}-1.58 \mu \mathrm{g} / \mathrm{g})$, iron $(0.27$ $\mu \mathrm{g} / \mathrm{g}-1.89 \mu \mathrm{g} / \mathrm{g})$, potassium $(6.61 \mu \mathrm{g} / \mathrm{g}-27.13 \mu \mathrm{g} / \mathrm{g})$, manganese $(0.26 \mu \mathrm{g} / \mathrm{g}-2.42 \mu \mathrm{g} / \mathrm{g})$, nickel $(0.23 \mu \mathrm{g} / \mathrm{g}-4.21$ $\mu \mathrm{g} / \mathrm{g})$, lead $(0.32 \mu \mathrm{g} / \mathrm{g})$ and $0.13-0.74 \mu \mathrm{g} / \mathrm{g}$ for zinc. The concentration levels magnitude of these elements detected in different kinds of the vegetable plant parts materials' was $\mathrm{K}>\mathrm{Ni}>\mathrm{Cd}>\mathrm{Mn}>\mathrm{Fe}>\mathrm{Cu}>\mathrm{Zn}>\mathrm{Pb}$, that is, the highest in concentration level was potassium $(\mathrm{K})$ and the least was lead, and these concentration levels were below and do not exceeded standard recommended safe limit proposed by WHO / AOAC / FAO. Thus, the irrigated vegetables cultivated in the studied area fit and found wholesome for consumption by both human and animals.

\section{Recommendations}

Based on the findings of this study, the need for restudy on the determinations of heavy metals and essential elements in irrigation fed vegetable plant parts materials cultivated along the bank of River Kumodu Gana in Maiduguri / Jere area, in order to find out and reveal the status of the irrigated vegetable plants, to screen and determine their metals and essential elements concentration levels, consumption fitness and their health risks status for human and animal benefits.

\section{Acknowledgement}

We acknowledge with most honoured, duly respected and most grateful to the Management of Mohamet Lawan College of Agriculture, Maiduguri and all persons who have helped and aided us in the course of carrying out this research study successfully.

\section{References}

[1] Akan, J. C; Kolo, B. G; Yikala, B. S, and Ogugbuaja V. O. (2012). Determinations of Some Heavy Metal in Vegetable Samples from Biu Local Government Area, Borno State, North-Eastern Nigeria: International Journal of Environmental Monitoring and Analysis. Volume 1, Number 2; Pp: 40 - 46. 10.11648/j.ijema.2013102.11.

[2] Alloway, B. J and Ayres D. C. (1997). Chemistry Principal for Environment Pollution, Blackie Academic and Professional, Pp. $190-221$.

[3] AOAC. Official Methods of Analysis. Association of Official Analytical Chemists, AOAC Press, Gaithersburg, USA, $15^{\text {th }}$ Edition.

[4] Ashiq, Hussain Lone; Eugenia, P. Lai; Sasya, Thakur; Ganie, S. A; Mohammed Saleem Wani; Ani Khare; Sajad Hussain Wani and Fayaz Ahmad Wani. (2013). Accumulation of Heavy
Metals on Soil and Vegetable Crops Grown on Sewage and Tube Well Water Irrigation, Academic Journals, Volume 8, Number 44; Pp: $2187 \quad-\quad 2193 . \quad$ http: $/ /$ www.academicjournals.org.SRE. Retrieved on $25^{\text {th }}$ November, 2013.

[5] Awofolu, O. D. R. A (2005). Survey of Trace Metals in Vegetables, Soil and Lower Animal along some selected Major Roads in Metropolitan, Lagos. Environmental Monitoring and Assessment, 105, 431 - 447.

[6] Awode, U. A.; Uzairu, A.; Balarabe, M. L.; Harrison, G. F. S.; Okunola, O. J. (2008). Assessment of Pepper and Soil for Some Heavy Metals from Irrigated Farmlands on the bank of River Challawa, Northern Nigeria, Pakistan Journal of Nutrition, Vol. 7 (2); Pp: 244 - 248.

[7] Bhata, S. C. (2002). Environmental Chemistry, CBS Publishers and Distribution, New Delhi; Pp. 442.

[8] Brown, K. H. and Carter, A. (2003). Urban Agriculture and Community Food Security in the United State or America, In: Farming from the City Centre to the Urban Fringe, Community Food Security Coalition, Venice, California.

[9] Bryce-Smith, D. Lead Pollution. (1971). A Growing Hazard to Public Health Chemistry in Britain. 7 (2) $54-56$.

[10] Bunce, N. J. (1990). Environmental Chemistry, Winners Publishing Ltd, Winnipeg, Canada; Pp. 206 - 247.

[11] Cobb, G. P; Sands, K; Waters, M; Wixson, B. G. and Dorward-King, E. L. (2000). Accumulation of Metals by Garden Vegetables, Journal of Environmental Quality, Vol. 29; Pp: $934-939$.

[12] Csuros, M and Csuros, C. (2002). Environmental Sampling and analysis for Metals, Lewis Publisher, CRC Press, New York; Pp. $237-238$.

[13] Estelle Levetin and Karen McMahon. (1999). Plant Life Cycle, Fruits and Seeds, In: Plants and Society, WCB/McGraw-Hill Company, Incorporation, U. S. A, $2^{\text {nd }}$ edition; Pp: 85 - 92. www.mhhe.com

[14] European Union. (2006). Commission Regulation (EU) No. 1881/2006, Official Journal of; European Journal of Public Health, Vol. 2 (suppl.); Pp: 40 - 44.

[15] Fischbein, A. (1992). Occupation and Environmental Lead Exposure in Environment and Occupation Medicine, Ron, WW (ed), Little Brown.

[16] Gwana, A. M.; Bako, M. M.; Bagudu, B. Y.; Sadiq, A. B.; Abdullahi, M. Mai. (2014). Determinations of Phytochemical, Vitamin, Mineral and Proximate Compositions of Varieties of Watermelon Seeds Cultivated in Borno State, North - Eastern Nigeria. International Journal of Nutrition and food Science, Vol. 3, No. 4, 2014, pp. 238 - 245. doi: 10.11648 / ijnfs. 20140304.12

[17] Gwana, A. M, Echeonwu, G. O. N, Auwal, M. S, Bagudu, B. Y, Mrs. Sa'adatu, H. S, Fatima, A. L, and Abdullah, S. (2012). Study Area and Location; In: Survey on Hepatitis B Surface Antigen (Hbs Ag) Amomgst the Community of Mohamet Lawan College of Agriculture, Maiduguri, Borno State, North - Eastern Nigeria. Journal of Laboratory Science, 2, (1); Pp: 1 - 6.

[18] Hornby, A. S. (2001). Oxford Advanced Learner's Dictionary, Oxford University Press, Great Clarendon Street, Oxford OX2 6DP, New York, $6^{\text {th }}$ edition; Pp: 479 and 1325. 
[19] Huges, M. K; Lepp, W. W and Philips, D. A. (1980). Industrial Heavy Metal Pollution and Termestial Ecosystem, Advance Ecological Research, 11: 217 - 227.

[20] Ibrahim Garba and Jimoh, W. L. O. (2015). Evaluation of Heavy Metal and Macro -Elements in Irrigated Vegetables from Challawa - Yandanko and Kano River Basin Project, Kano, Internatinal Journal of Scientific Research and Engineering Studies, Volume 2, Issue 2.

[21] Jayedev, E. and Puttah, T. (2013). Assessment of Heavy Metals uptake in leafy vegetables grown on long term waste water irrigated soil across Vrishabhavathi River, Bangalore, Karnataka, Journal of Environmental Science, Toxicology and Food Technology, Vol. 7; Pp: 52 - 55. Website: www.iosrjournals.org.

[22] Jimoh, W. L. O. and Mahmud, I. M. (2012). Toxic Metal Uptake by Cabbage Grown in Irrigated Farmlands of Kaduna Metropolis, Nigeria, Research Journal of Applied Science, Engineering and Technology, Vol. 4 (23); Pp: 4939 - 4957.

[23] Jules Janick. (1972). Horticultural Science, H. W. Freeman and Company, U.S.A, $2^{\text {nd }}$ edition; Pp: $32-39$.

[24] Ladipo, M. K and Doherty, V. F. (2011). Heavy Metals Levels in Vegetables from Selected Markets in Lagos, Nigeria. African Journal of Food Science and Technology, Vol. 2 (1); Pp. $018-021$.

[25] Meittinien, J. K. (1975). The Accumulation and Excretion of Heavy Metalals in Aquatic Environment, Peter A. (ed) Krenkal Perganon Press; Pp: 155.

[26] Muhammad Farooq, Farooq Anwar and Umer Rashid. (2008). Appraisal of Heavy Metal Contents in Different Vegetables Grown in the Vicinity of an Industrial Area. Pak Journal Botany, Vol. 40 (5): Pp. 2099 - 2106.

[27] National Institution Occup. Safety and Health. (1976). NIOSH "Criteria for Recommended Standard Occupational Exposure to Cadmium" H. E. W. Publication Co. (NIOSH); Pp: $76-$ 192.

[28] Nirmal Kumar, J. I; Hiren Soni and Rita N. Kumar. (1997). Characterization of Metals in Vegetables Using Inductive Coupled Plasma, Journal of Applied Science, Environmental and Management, Volume 11, Number 3; Pp: $75-79$. www.bioline.org.br/ja.
[29] Okoronko; N, Igwe; J. C, and Onwuchelcua; E. C. (2005). Risk and Health Implication of Polluted Soil for Crop Production. American Journal of Biotechnology. Vol. 4, No. B, Pp: $1521-1524$.

[30] Qais Abdullah Nogaim, Mohammed Mukarem, Mosa Alwah and Mukhtar Atef. (2013). Survey of Some Heavy Metals in Yemeni Vegetables, Merit Research Journal of Food Science and Technology, Volume 1 (3) Pp: 036 - 42.

[31] Rao, L. M and Patnaik, M. S. (1999). Heavy Metal Accumulation in Catfish, Mystus vittatus (Bloch) from Mehadrigedda stream of Vishakhapatnam, Indian Environ Media, Volume 19, Number 3; Pp: 325 - 329.

[32] Sharma, B. C; Mishra, A. K. and Bhattacharya, K. G. (2000). Metal in drinking Water in a Predominantly Rural Area, Indian Journal Environmental Protection, Volume 21, Number 4; Pp: 315 - 322.

[33] Stroud, K. A and Booth, D. J. (2001). Statistical Package, In: Engineering Mathematics WWW. Palgrave.Com / Stroud, Pal grave. GB, London, $5^{\text {th }}$ Edition; Pp: $1130-1139$.

[34] USEPA. United State Environmental Protection Agency. (1986). Quality Criteria for Water. Office of Water Regulation and Standards, Washington DC, Pp: 20460.

[35] Watt, J., Thornton, I., and Cotter, Howells J. (1994). Physical Evidence Suggesting the Transfer of Soil Lead $(\mathrm{Pb})$ in to Young Children via Hand to Mouth Activity. Appl. Geochem. (2): $269-272 ;$ Pp: 15.

[36] Wikipedia. (2008). Metal toxicity, In: Free encyclopaedia, Dartmouth Toxic Metal Research - Toxic Metals (2008a).

[37] Wikipedia. (2008). Metal Toxicity, In: Announcement: Response to the Advisory Committee on Childhood Lead Poisoning Prevention Report, Low Level Lead Exposure Harms Children: A Reviewed Call for Primary Prevention. CDC (2008b).

[38] WHO / AOAC. Safe Limit. $2^{\text {nd }}$ revision, section $973-42 B$ (b).

[39] Xiong, Z. T. (1998). Lead Uptake and Effects on Seed Germination and Plant Growth in a Lead $(\mathrm{Pb})$ Hyper accumulator Brassica pekinensis Rupr. Bulleting of Environmental Contamination and Toxicology, 60; Pp: $285-$ 291. 